\title{
Federalism-E \\ Balancing Power: The Supreme Court of Canada's Impartial Role in Federalism
}

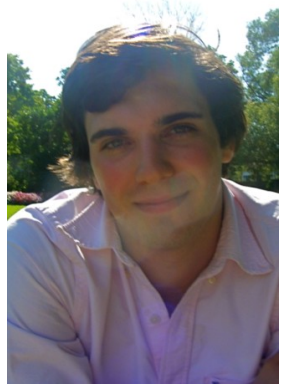

Darcy Drury

McGill University

"The true natural check on absolute democracy is the federal system, which limits the central government by the powers reserved, and the state governments by the powers they have ceded."

- Lord Acton

Lord Acton. Fasnacht, Acton's Political Philosophy. 244 (1952).
The problem with Lord Acton's statement is that it leaves out the third essential ingredient to a federal system of government: a supreme court. In Canada, like most federations, the Supreme Court (SC) is responsible for articulating the constitution and serving as an independent mediator in intergovernmental relations. Each decision made by the SC in regards to government jurisdiction changes the dynamics of Canadian federalism, and some critics fear it can be used as a centralizing device by the federal government. This paper will discuss the nature of the SC by demonstrating its necessity, purpose, and the importance of its independence by examining its crucial role in Canadian federalism. Next, there will be a historical breakdown of the impact of 2 the SC on the federal balance of powers through an examination of three essential eras: Judicial Committee of the Privy Council (decentralizing), Laskin (centralizing), and Charter (mixed), with analysis involving the attitudinal and legal theorist models of decision making in SC decisions. Finally, the SC's impartiality towards provincial and federal preferences will be evaluated to show that justices have remained immune to direct political pressures. This paper will ultimately argue TThisf that that the SC mediates the balance of power in intergovernmental relations by acting as an impartial articulator of the constitution. Its decisions, however, impact federal centralization throughout Canadian history due to a constant use of the attitudinal model in the decision-making process.

In order to understand the role of the $\mathrm{SC}$ as a federalist institution, it is important to begin by explaining the concept of federalism and the reasons why a nation will choose to develop a federalist system of governing. A federal system of government is one that divides the powers of government between the national (federal) government and the independent state (provincial) governments. Typically, federal governments are established if the population of a country appears to contain significant linguistic, geographical, cultural or economic differences. ${ }^{1}$ In 1867 , these four attributes, among others, were apparent in British North America, most notably in the French-speaking colony of Quebec, which maintained a uniquely Catholic view and had an agricultural-centered economy. This can clearly be contrasted with Ontario, which was mainly comprised of English-speaking Protestants concerned with developing industry. As political scientist Richard Simeon explains, "The fundamental basis for federalism in Canada [...] was and remains the need to reconcile, balance and accommodate diversity. ${ }^{2}$ The natural issue that evolves from federations is the balance of provincial and federal authority in determining jurisdiction over key powers. The BNA Act of 1867--the original Canadian Constitution--clearly designates certain roles to the federal government (i.e. trade and commerce) and to the provincial governments (i.e. property and civil rights), as well as concurrent (shared) powers such as agriculture or immigration. To resolve discrepancies in the less clear areas of jurisdiction it is essential to have an independent body of authority.

The SC was established as the highest court of appeal in Canada not in the BNA Act, but rather as a part of legislation in 1875, in under permission of Section_101 (BNA Act). As Harvard Law professor Paul Freund notes, "Every federation has thought it necessary to establish a supreme court which performs the twofold function of interpreting the constitution and promoting the uniformity of law." ${ }^{3}$ Without a supreme court, governments run the risk of a constitutional disagreement turning into more serious problems. An example of this is the United States' Civil War (18611865), which resulted from a polarization of two groups, where the Confederates' appeals against the federal government were "always on constitutional grounds." ${ }^{4} \mathrm{An}$ increased legitimacy of the court system could have, in theory, helped prevent this war; a case which demonstrates the importance of a universally accepted SC within a regime. 


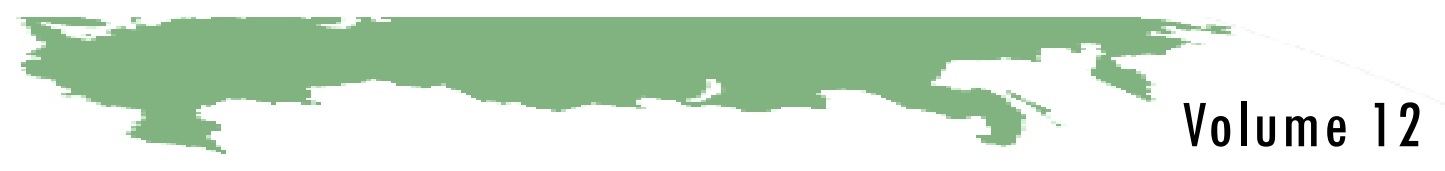

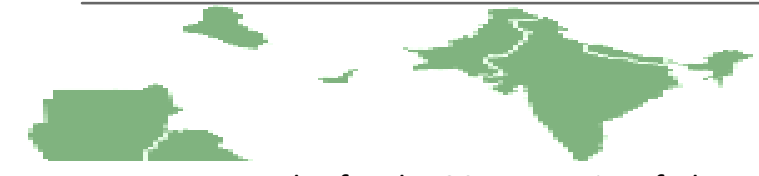

In order for the SC to remain a federalist institution rather than a federal device, it is assumed that judicial independence is necessary for the court system's legitimacy. Judicial independence is the essential provision that maintains law and order between governments, as it helps keep the judiciary outside both federal and provincial politics. It requires several elements: administrative independence from government, reasonable salaries, and tenure--all of which are found within the original BNA Act. ${ }^{5}$ These requirements are essential "to assure the public, both in appearance and reality, that their cases will be decided, their laws will be interpreted, and their Constitution will be applied without fear or favour." ${ }^{6}$ In the context of Canadian federalism, judicial independence remains the safeguard against illegitimate centralizing or decentralizing attempts by the governments.

Within the framework of Canada's federal system, the SC operates as an independent body that serves as the intergovernmental mediator. It is important to note that "a decision by a s.101 court applies equally anywhere in Canada," ${ }^{\prime 7}$ and thus the SC must ensure that prudent decisions result from their deliberations. This inherently shapes the SC into a centralizing agent, not of the federal government, but of its own prerogative, furthering the importance of judicial independence. Although sec. 101 courts may hear interprovincial and federal-provincial disputes, the SC's power of judicial review ensures its dominance over the entire judicial system due to the finality of its judgments. The final interpretation of the Constitution rests in the hands of the SC, therefore governments--as litigants--must be careful in the disputes they bring to court, since a decision may end up hurting their jurisdiction over a certain area . An example of this can be found in R. v. Crown Zellerbach (1988), which held the validity of the Ocean Dumping Act as constitutional because, although provinces have control of resources, environmental protection is considered to be national jurisdiction under the POGG clause (peace, order and good government). While attempting to strike down federal legislation, the finality of the $\mathrm{SC}^{\prime}$ 's judgment caused jurisdiction over all water pollution to become national jurisdiction-including lakes and rivers. As is evident in this case, the role of mediator can be a burden on justices, especially with increasing media attention covering their more important decisions $^{8}$, and therefore it is important to examine the factors that are involved with such cases.

In Canada there are several theories that help explain the process of judicial decision making, most notably the attitudinal model and legal theory. Legal theorists propose that justices consider precedent and framers intent when deliberating on cases. From a conservative approach to legal studies, it appears, through justice opinions, that the intent of legislatures and constitutional framers while positing these laws is concrete and frozen. It is therefore the judge's simple task to apply the facts of the case to the law and, if necessary, to use former cases as guidance under the doctrine of stare decisis--"to stand by decisions and not disturb the undisturbed"9. The problem with the legal model is that it does not adequately account for the significant shifts in governmental power and jurisdiction. that have occurred in Canadian history .

A more comprehensive approach to judicial decision-making is the attitudinal model, which is derived from empirical evidence that justice ideology and political preference directly impact Supreme Court decisions. ${ }^{10}$ This evidence comes from studies of both the American and Canadian SCs, and attributes the finality of judicial review as an unchecked power that allows justices to posit their opinions as law. Thus, judicial independence strengthens the argument for the relevance of the attitudinal model because, since judges have sole jurisdiction over intergovernmental relations, they are "free to simply select precedents that reflect their own point of view."11 Although this assertion may be severe, it is 


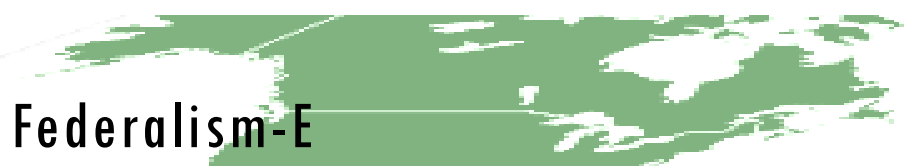

not unreasonable to recognize the impact this sort of freedom must have on the balance of power within federal relations. The attitudinal model has relevance in Canadian history; it is well documented that the Judicial Committee of the Privy Council (JCPC)--the British court that served as Canada's highest court of appeal from 18671960--ruled on several cases in favour of British policy objectives. The effects of these decisions created the parameters for the future of Canadian intergovernmental relations.

To discern whether the Supreme Court has exerted a centralizing tendency in its decisions, Canadian judicial history can be broken down into three main eras: the decentralizing JCPC era, the centralizing Laskin era, and the Charter era. Each of these periods represents a change in general judicial decision making, as well as a significant shift in the balance of powers within a federalist context. In regards to what is meant by centralizing, it is assumed to mean enhanced federal jurisdiction over elements of society by obtaining power from what was once considered to be provincial jurisdiction--decentralization is the contrary.

The first era in the history of the Supreme Court was the period marked by the JCPC, which shaped the first methodological approaches to reading the Constitution. It is important to note that the JCPC and the SC were very often consistent with their opinions; as Freund articulates, "there was no dramatic contest between the Privy Council and the Supreme Court of Canada." ${ }^{12}$ A significant case that began a decentralizing trend in Canadian federalism was Citizens' Insurance Co. v. Parsons (1881). This was the first constitutional case to be heard by the JCPC, and it resulted
Constitutional scholar Katherine Swinton describes Laskin as a man with "firm views" on how the BNA Act should have been interpreted, mainly as a product of "the problems of the Depression". His upbringing led to him viewing provinces as "unable to provide adequate[ly]"17 for their citizens, and one who saw "the wisdom of a strong federal government in this period." ${ }^{18}$ His views were confirmed in his judgments as a justice ${ }^{19}$, which suggests a strong attitudinal tendency within the SC in this era.

The issue that scholars, justices, and politicians had to face in this era was whether they should interpret the Constitution as written, now that they were not subject to the JCPC, or whether the precedents set by the last century should be maintained. The result, unsurprisingly, was a series of decisions that allowed the federal government to take back control of its originally intended jurisdictions--namely trade and commerce. In Caloil Inc. v. Attorney General of Canada (1971), Laskin took the opportunity to write a concurrent judgment that allowed the federal government to "regulate the local as well as international and interprovincial stages of trade." ${ }^{20}$ The impact of this opinion, as well as several others such as Manitoba Egg Reference, caused Laskin to create a "new rule" that cut down on provincial barriers of goods. ${ }^{21}$ As he encouraged centralized trade in Canada with his judgments, he took this a step further in Reference re Anti-Inflation Act by asserting that wage and price control were emergency federal powers under POGG. ${ }^{22}$ The impact of the judgments from the Laskin era strongly centralized the powers of the federal government.

As exceptionally attitudinal as Laskin appeared by his judgments, his reasoning always pulled out the textualism of the constitution as a means to impartially interpret the law. His disapproval of the JCPC's interpretation of 


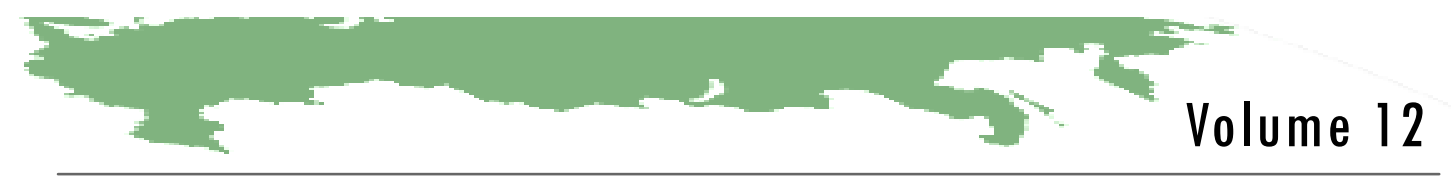

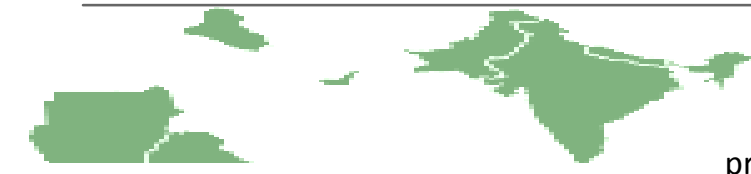

intergovernmental relations was clearly and makes way for "new national standpresent in many of his power-shifting judg- ards...as interpreted by the courts." 24 ments. Whether he was attempting to de- The question of central concern for convelop policy using judicial review, or fix the temporary Canadian federalism is whethmisinterpretations of past decisions, he er the Charter has significantly affected was clearly a strong proponent of the the balance of powers, and if so, whether "living tree-doctrine", which allows consti- this is due to an attitudinal or legalist tutional judgments to reflect the current interpretation of the Constitution by the times without contradicting the past. He SC.

used this doctrine to override JCPC judgments in order to bring Canadian federalism back to its original intent. Swinton contends Laskin's court was "wise to show restraint in taking new directions" with a strong "commitment to the rule of law". ${ }^{23}$ To prove his impartiality between federal and provincial jurisdiction, in Reference re a Resolution to amend the Constitution (1981) he invoked an unwritten constitutional convention to restrict the federal government from amending the constitution without provincial consent. It is clear that there is a relationship between Laskin's conceptions of Canadian Constitutional law and his judgements; however, his attitudinal decision-making did not seek to grant extra-constitutional powers to either the provinces or the states. The legacy of Laskin's court leads directly into the modern era, which bring in a new Constitution and a written Charter of Rights.

The introduction of the Charter court may use; and section 33, the notand the patriation of the Constitution in withstanding clause that allows govern1982 altered the balance of powers in Ca- ments to override certain sections of the nadian politics. Due to the history of the SC constitution. These clauses, however, are being given judicial discretion, as well as only effective to a degree. For example, the new jurisdiction in which it can decide "the Court's willingness to accept provincases, the Canadian SC now holds a signifi- cial differences as a legitimate basis for a cant degree of legitimate authority over 'reasonable limitations' defense under the validity, impact, and implementation of the ubiquitous Section 1 of the Charter" laws. F.L. Morton explains this change by has helped maintain the existence of stating that the Charter "challenged the dual federalism (two spheres of sovertwo institutional foundations of Canadian eignty); although some important section polity: Parliamentary supremacy and feder- 1 cases have been rejected; for example, alism." The result is what he calls there has been an "extensive nullification "constitutional supremacy", which curtails of various Quebec language policies." 27 It is decisions such as these that suggest the prevalence of attitudinal decisions, which increasingly adhere to a nationalistic agenda and popular--although extra-provincial--opinion. These safeguards exert neither a centralizing, nor decentralizing tendency in the federal makeup on their own, but with the prevalence of attitudinal interpretation, their impact is uncertain.

Although these safeguards exist, the implementation of the Charter has also had strong centralizing tendencies, and provinces have lost significant jurisdiction: the new Bill of Rights (1982) directly contradicts the sec. 92 provincial power of civil rights and liberties. Most notably, Quebec sovereignty has particularly come under redress; political scientist Guy LaForest considers the Charter "undoubtedly the most significant event in the evolution of Canadian political culture in the twentieth century," 28 upon which Morton adds, "and much to the detriment of Quebec." 29 Originally, Quebec symbolically invoked the notwithstanding clause for all its laws, but after their 5-year expiration--and a new Liberal government-they were not renewed. As a result, there was a strong push for Quebec succession in the early 1990s, which nearly succeeded. This demonstrates the ineffectiveness of such federal safeguard clauses as ways to prevent the natural centralizing tendency of the Charter, and shows the direct link between the Charter and the centralizing implications it brings on the provinces.

Apart from direct legal and constitutional influences, the modernday centralizing of Canadian federalism is not solely due to the SC and the Charter. It is in this realm that Swinton makes an astute contention: regardless of pressures from Quebec and the 


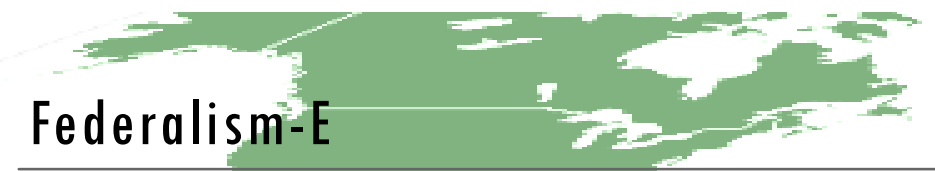

West to decentralize, increasing globalization has caused Canada to become more centralized in order to play a stronger role in the international community. ${ }^{30}$ International commitments such as NAFTA or ICESCR (Human Rights) indirectly force Canada to become more cohesive in order to strengthen its role both economically and politically. As mentioned above, the decision in Crown had a centralizing effect on Canadian federalism, although legalistically "the addition of ocean waters...was a modest accretion and quite defensible." ${ }^{31}$ Swinton's main argument here is that new considerations must enter the process of decision-making, which regard federal and provincial interests equally. She does not articulate whether an attitudinal role in making these modern decisions is necessary, only that there must be a "case-bybase examination of the demand for an expanded role. ${ }^{132}$ Swinton advocates that more deliberation is needed when making these complex decisions, and it is clear that she regards the SC as fully capable of making a mutuallybeneficial, and impartial, decision.

The final issue to be discussed is the impartiality of the SC between the provinces and parliament. It is important to recognize that the SC is an independent body and, in theory, has no political ties to either the federal or provincial governments. Independence, however, refers to the SC as an isolated third party, whereas impartiality is a "state of mind or attitude...connotat[ing] absence of bias, actual or perceived." ${ }^{\prime 33}$ Although created through an Act of Parliament, the $\mathrm{SC}$ became entrenched in the Constitution Act of 1982, giving Constitutional legitimacy to its existence. This legitimacy has allowed the SC to be impartial in its nature, although it is evident that individual justices throughout Canadian history have

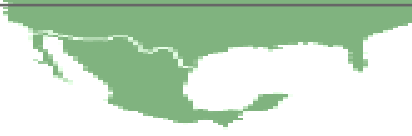

had specific preferences.

It cannot be argued that all justices of the SC have consistently remained unaffected by personal or political preference in their decisions, since this has been demonstrated by the attitudinal model's consistency throughout Canadian history. What is clear is that, until the adoption of the Charter, the balance of powers had never become too unstable that a constitutional crisis emerged in this field. Constitutionality has remained supreme in Canada throughout history, and this is proven by the fact that all major centralization decisions have been argued and resolved on constitutional grounds. The existence of the attitudinal model has caused swings in the pendulum, beginning with the JCPC's precedent of disregarding framer's intent; however, it is clear that the Laskin era brought with it a stabilizing tendency in order to bring Canada back to its initial constitutional arrangements. Although Laskin appeared to have a centralizing agenda, his decision in Re: Amendment demonstrates a strong impartiality towards the subject and a most severe deference to the rule of law.

The reconciliation of the attitudinal model and judicial impartiality can exist in Canada, against their seemingly contradictory natures. Ostberg and Wetstein establish several reasons that are uniquely Canadian, which help clarify this divergence from the traditional US model: a "tradition of cultural deference, a political system based on parliamentary dominance, a less politicized appointment process, and the institutional norm of consensus". ${ }^{34}$ Reasons such as these evolve from the historical context and current existence of a monarchical presence within the law system. The existence of unwritten laws and conventions, such as the flexibility of the POGG clause, help ensure political and judicial stability. Morton demonstrates the importance of the uniquely Canadian context by noting that, although the Charter era may have garnered increasing activism on the part of judges, there is no evidence to "support the centralizing hypothesis generated by the analogous American experience." 35 The lack of evidence regarding the centralizing nature of the Charter demonstrates the impartiality of the SC between provinces and the federal government, although Morton is clear in pointing out that "Charter politics extend well beyond the courtrooms, and this is where its effects on provincial power have been most pronounced." 36

The Supreme Court of Canada is a federalist institution that has shaped the balance of powers between the provincial and federal governments through its interpretation of the Constitution. It is clear that the attitudinal model of decision-making has consistently played a role in how justices of the SC have reached their decisions, although there is no clear evidence to suggest that the SC, through interpreting the Constitution or the Charter, has had a consistent agenda in shaping the federal makeup of Canada. As an independent and, in areas of intergovernmental jurisdiction, impartial institution, the SC has gone through three main eras in regards to its impact on centralization: JCPC, Laskin, and Charter. Each of these periods mark significantly unique directions for the federal condition in Cana$\mathrm{da}$, and involve distinct factors that adjust the balance of power between governments. As the prevalence of the attitudinal model alludes, the SC has never been a static body; although if history is to remain consistent, it can be stated that the SC will remain largely fair and impartial in the future. 

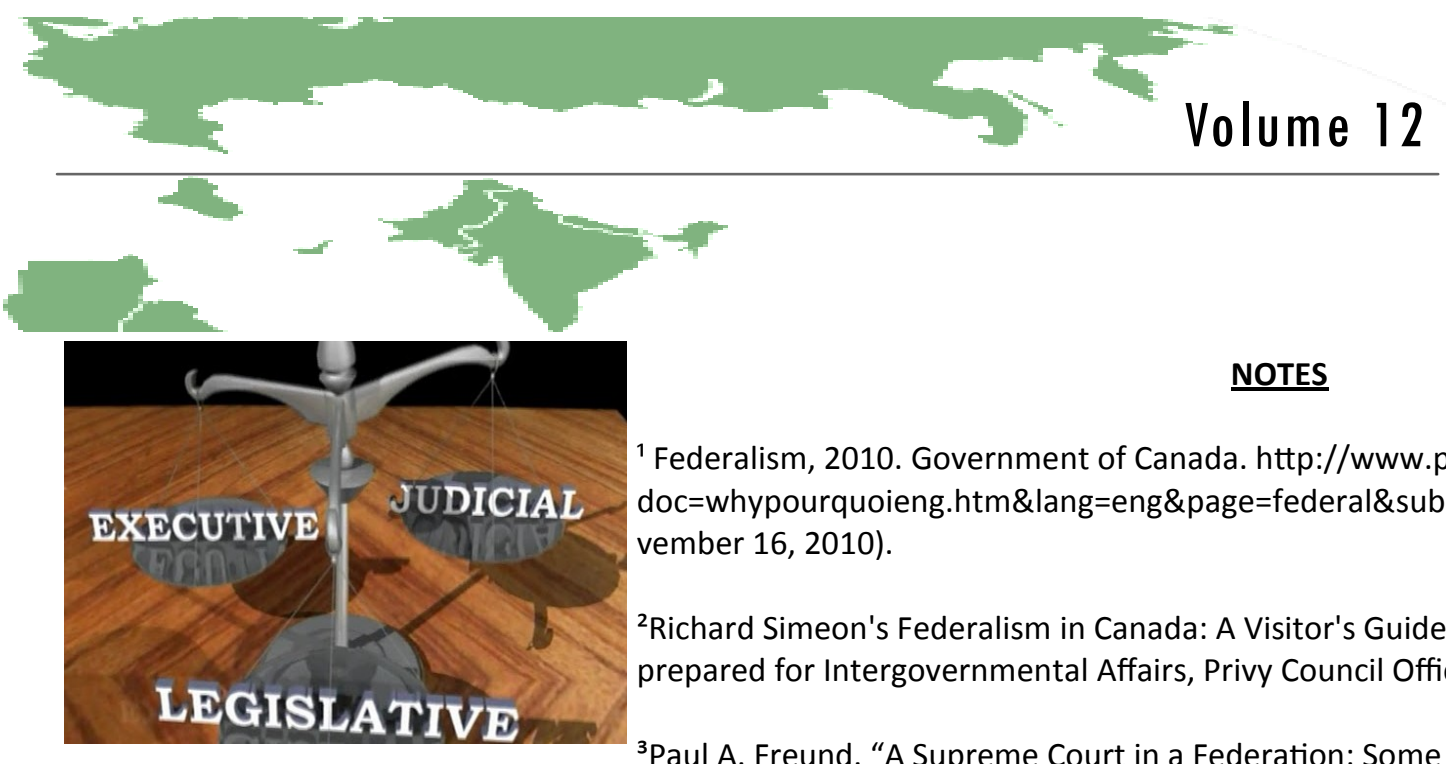

Finding Balance

${ }^{3}$ Paul A. Freund. "A Supreme Court in a Federation: Some Lessons from Legal History". Columbia Law Review. 53 (May, 1953), 598.

\section{NOTES}

1 Federalism, 2010. Government of Canada. http://www.pco-bcp.gc.ca/aia/index.asp? doc=whypourquoieng.htm\&lang=eng\&page=federal\&sub=why-pourquoi\# (accessed November 16, 2010).

${ }^{2}$ Richard Simeon's Federalism in Canada: A Visitor's Guide, 2002 (unpublished document prepared for Intergovernmental Affairs, Privy Council Office). lumbia Law Review. 53 (May, 1953), 598.

${ }^{4}$ Forrest McDonald. States' Rights and the Union: Imperium in imperio. (Kansas: University of Kansas Press, 2008), 117.

${ }^{5}$ Lori Hausegger et. al. Canadian Courts: Law, Politics, and Process. (Don Mills: Oxford University Press, 2009), 175.

${ }^{6}$ Justice Barry Strayer, Gratton v. Canadian Judicial Council (1994, para. 16).

${ }^{7}$ Hausegger, 59

${ }^{8}$ Hausegger, 135.

${ }^{9}$ Gabriel Adeleye et al. World Dictionary of Foreign Expressions: a Resource for Readers and Writers. (1999), 371.

${ }^{10}$ Cynthia Ostberg et. al. Attitudinal Decision Making in the Supreme Court of Canada. (Vancouver: UBC Press, 2007), 5.

${ }^{11}$ Ibid., 9.

${ }^{12}$ Freund, 608.

${ }^{13}$ Citizens' and The Queen Insurance Cos. v. Parsons, (1880), 4 S.C.R. 215. http://scc.lexum.umontreal.ca/en/1880/0scr4-215/0scr4215.html (accessed November 15, 2010).

${ }^{14}$ Robert Vipond. Libert and community: Canadian federalism and the failure of the Constitution. (New York: SUNY Press, 1991), 170.

${ }^{15}$ Parliamentary Debates on the Confederation of the British North American Provinces 33 (1865).

${ }^{16}$ Vipond, 152.

${ }^{17}$ Katherine Swinton. “Bora Laskin and Federalism.” University of Toronto Law Journal. 35 (1985) 356-357.

${ }^{18}$ Swinton, 357.

${ }^{19}$ Ibid., 356. 


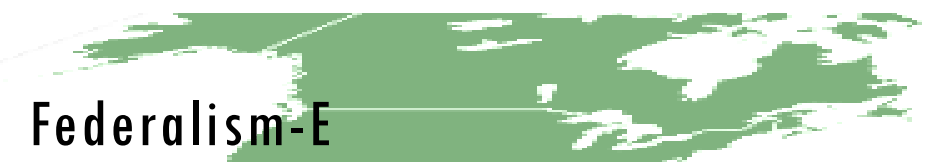

${ }^{20}$ Ibid., 360.

${ }^{21}$ Ibid., 361.

${ }^{22}$ Ibid., 375.

${ }^{23}$ Ibid., 386-7.

${ }^{24}$ F.L. Morton. "The Effect of the Charter of Rights on Canadian Federalism." The State of American Federalism. (Summer 1995), 174.

${ }^{25}$ Ostberg, 40.

${ }^{26}$ Ibid., 40.

${ }^{27}$ Morton, 175 .

${ }^{28}$ Guy LaForest. Trudeau and the End of a Canadian Dream. (Montreal and Kingston: McGill-Queen's University Press, 1995$), 125$.

${ }^{29}$ Morton, 173.

${ }^{30}$ Katherine Swinton "Federalism under Fire: The Role of the Supreme Court in Canada" Law and Contemporary Problems. 55 (1992), 121.

${ }^{31}$ Ibid., 136-137.

${ }^{32}$ Swinton, 137.

${ }^{33}$ Hausegger, 174.

${ }^{34}$ Ostberg, 43.

${ }^{35}$ Morton, 176.

36 Ibid., 177.

Works Cited:

Adeleye, Gabriel et al. World Dictionary of Foreign Expressions: a Resource for Readers and Writers, (1999).

Citizens' and The Queen Insurance Cos. v. Parsons, (1880), 4 S.C.R. 215. http://_scc.lexum.umontreal.ca/en/1880/0scr4-215/0scr4215.html (accessed November 15, 2010).

Federalism, 2010. Government of Canada. http://www.pco-bcp.gc.ca/aia/index.asp? doc=whypourquoieng.htm\&lang=eng\&page=federal\&sub=why-pourquoi\# (accessed November 16, 2010).

Freund, Paul. "A Supreme Court in a Federation: Some Lessons from Legal History”. Columbia Law Review. 53 (May, 1953). Hausegger, Lori et. al. Canadian Courts: Law, Politics, and Process. Don Mills: Oxford University Press, 2009. 

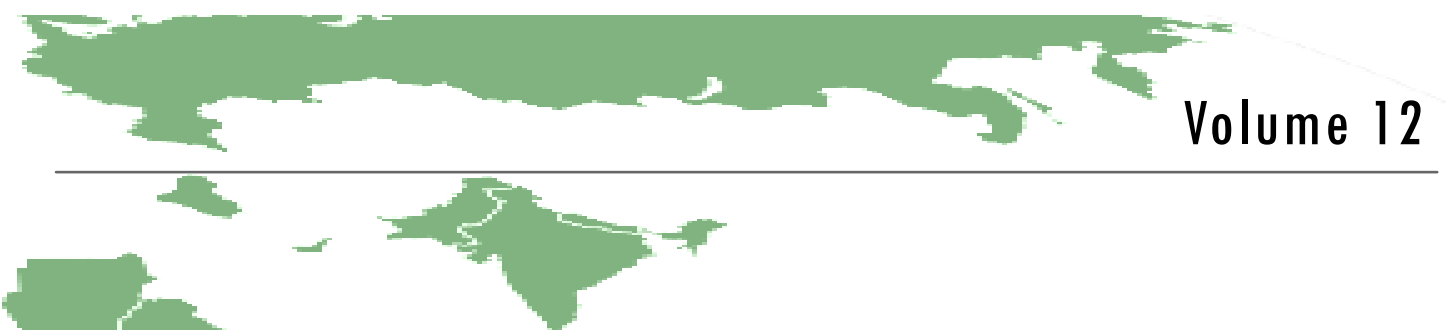

Justice Barry Strayer, Gratton v. Canadian Judicial Council (1994).

LaForest, Guy. Trudeau and the End of a Canadian Dream. Montreal and Kingston: $\quad$ McGill -Queen's University Press, 1995.

Lord Acton. Fasnacht, Acton's Political Philosophy. 244 (1952).

McDonald, Forrest. States' Rights and the Union: Imperium in imperio. Kansas: University of Kansas Press, 2008.

Morton, F.L. "The Effect of the Charter of Rights on Canadian Federalism."

The State of American Federalism. (Summer 1995).

Ostberg, Cynthia et. al. Attitudinal Decision Making in the Supreme Court of Canada. V Vancouver: UBC Press, 2007.

Parliamentary Debates on the Confederation of the British North American Provinces 33 (1865).

Simeon, Richard. Federalism in Canada: A Visitor's Guide, 2002 (unpublished document prepared for Intergovernmental Affairs, Privy Council Office).

Swinton, Katherine. "Bora Laskin and Federalism." University of Toronto Law Journal. 35

(1985).

Swinton, Katherine. "Federalism under Fire: The Role of the Supreme Court in Canada" Law and Contemporary Problems. 55 (1992).

Vipond, Robert. Liberty and community: Canadian federalism and the failure of the Constitution. New York: SUNY Press, 1991. 